LEARNING STRATEGIES OF HIGH ACHIEVEMENT STUDENTS IN ENGLISH OF SMA DHARMA PANCASILA MEDAN

\begin{abstract}
AN ARTICLE
Submitted in Partial Fulfillment of the Requirements for the Degree of Sarjana Pendidikan
\end{abstract}

SISCA INDAYANI DAMANIK

Registration Number: 2153321034

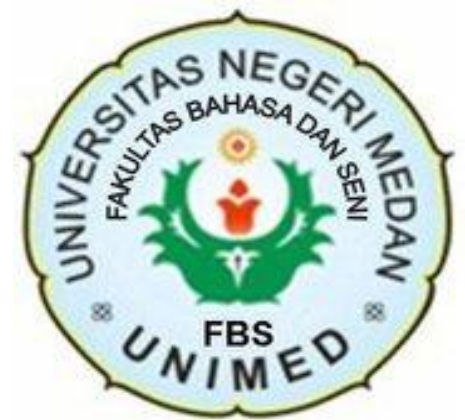

ENGLISH AND LITERATURE DEPARTMENT

FACULTY OF LANGUAGES AND ARTS

UNIVERSITAS NEGERI MEDAN

2021 


\title{
LEARNING STRATEGIES OF HIGH ACHIEVEMENT STUDENTS IN ENGLISH OF SMA DHARMA PANCASILA MEDAN
}

\author{
*Sisca Indayani Damanik \\ ** Masitowarni Siregar
}

\begin{abstract}
Sisca Indayani Damanik. Registration Number: 2153321034. Learning Strategies of High Achievement Students in English of SMA Dharma Pancasila Medan. English Educational Program, Universitas Negeri Medan, 2021.
\end{abstract}

Learning English is one of the important things for students to acquire English well. Many students are still confused to choose what are the strategies that appropriate for them. Several strategies can be used for students to get higher achievement. Meanwhile, students have individual characteristics related to their learning processes, the used of the strategies will give big impact for their achievement. Students whose have high achievement also have their own strategies in their learning process. This is why this research interesting. The objective of the study was known what are the learning strategies used by high achievement students of SMA Dharma Pancasila Medan. By using questioner and interviewed which is adopted from Strategy Inventory for Language Learning (SILL) version 7.0 (ESL/EFL) by Oxford (1990) translated into Bahasa Indonesia to avoid misinterpretation and misunderstanding. The study's result was based on the answers using yes/no questions to determine whether students used direct or indirect strategies, from the interview session followed by the three high achiever students of SMA Dharma Pancasila Medan. The first students tend to used memory, metacognitive and compensation strategies as the main strategies. The second high achievers employed cognitive, metacognitive, and compensation strategies as the main strategies in learning English. Meanwhile, the third used memory, cognitive and social strategy as the main strategies. The data showed the students combined all strategies in the learning process and used three strategies as the main strategy.

Keywords : English, Learning Strategies, Achievement.

\footnotetext{
* Graduate Status

** Lecturer Status
}

INTRODUCTION 
Since English is used as an international language, nowadays many people, particularly students, ought to master the English language. English is naturally difficult to master. Seeing this phenomenon, the Indonesian government has made a regulation that English as the subject has to be taught at Elementary School, Junior High School, and Senior High School. There has been a significant change in the language learning areas from teacher, teaching to learning learners.

Learning English is one of the important things for students to acquire English well. Hilgrad (1984: 4) said learning is the process by which the learning activity originates or is changed through training procedure (whether in the laboratory or the natural environment) as distinguished of change by a factor not attributable to training. This means that the students were still important to learn about English.

According to Reiff (1992) students have individual characteristics related to their learning processes. Indonesian's teachers nowadays teach English by following the methods suggested in curriculum 2013. The method is suggested by the curriculum already tested by experts and adapted to foreign language learning, especially English as the most prioritized foreign language. It means, in general, the English learning materials and methods used by teachers in schools have similarities. Students received the materials and teaching method that is not much different, the material and teaching methods are the same, it means indirectly, the learners have problems with their learning process or used different learning strategies in their learning process.

Once the researcher interviewed with the English teacher and some students at SMA Dharma Pancasila Medan, based on the data on the test result of a class in 2019/2020 shows, all most students passed the Minimum Completeness Criteria Score (KKM) and even very well. The English teacher said the exciting, even though in learning English process 
students showed a different level of interest in their style, and they still achieved a good score, this fact indicated students have their own way in learning English. The result of the interview with some students showed they combined some different strategies which some of them referred to motivation, social and memory strategies. A student admitted, she had difficulty in learning English, and take another English class out of the school to help remind the materials. From the explanation above the students refers used direct and indirect strategies in their learning English process (Oxford, 1990).

From the explanation of the interview, even though they are in the same class with the same teacher they have and know how to overcome their difficulties in learning English in different ways and get the best score. Several strategies can be used by the students to help them in their learning process. Strategies in learning English can be a facility to get the higher achievement because the students can use different strategies. However, not all suggested methods can be fitted to all students with a different learning environment that affect their ways of learning.

Many students in senior high school still have difficults to find out the best strategy that they have to use to learn English. Rubin (1975) mentioned a good language learner may have some special or using some mixed strategies. Therefore, choosing the best strategies is important when learners learn about English. Language teaching can be successful if there is knowledge which is sufficient towards learner's traits and behavior. In a learning process, there are always learners who are well manage and the learner less successful.

This study involves the second grade of SMA Dharma Pancasila Medan which is one of the best senior high schools in Medan. This school is chosen as the research setting because all classes are regular class and each class has its own high achiever. Once the researcher did The Minimum Completeness Criteria (KKM) in English subject is $77 / 100$ points. Students at SMA Dharma Pancasila Medan have higher achievement with their 
different strategies in learning English, where in national standard KKM is expected to touch $75 / 100$ in every subject, while the average score of English in each class already reach more than 75 in the first grade in 2019.

High achievement is defined as a level of performance that is higher than one would expect for students of the same age, grade, or experience. Based on the regulation of the minister of Education and Culture (Kermendikbud) number 14 of 2018 concerning the Admission of New Students (PPDB), the education system in Indonesia has a minimum and maximum age to enter school, it is mean at same grade there are the same ages and there is no significant difference age between students.

There must be factors or ways how the students get high achievement where the test score in English subject can reach the maximum score. From their strategies or motivation when they learn about English and, the way the teacher teach English or it could be from society.

\section{THEORY}

\section{A. Learning Strategies}

Oxford (1990) said that the word 'strategy' comes from the term strategia. It is an ancient Greek term which is mostly used for the war that means generalship or the art of war. The word strategies influences to any setting, including education. Oxford (1990:17) also drew learning strategies into two major divisions. In this regard, Oxford's taxonomy classified language learning strategies into two main types of strategies; direct strategies and indirect strategies. The language learning strategies that involve the target language directly named natural language, all of the direct strategies need mental processing. Otherwise, "indirect strategies provide indirect support for language learning through focusing, planning, evaluating, seeking opportunities, controlling, anxiety, increasing cooperation and empathy, 
and other means" (1990, p. 151). To make it more straightforward, here are the figures that illustrate the language learning strategies classification created by Oxford (1990) :

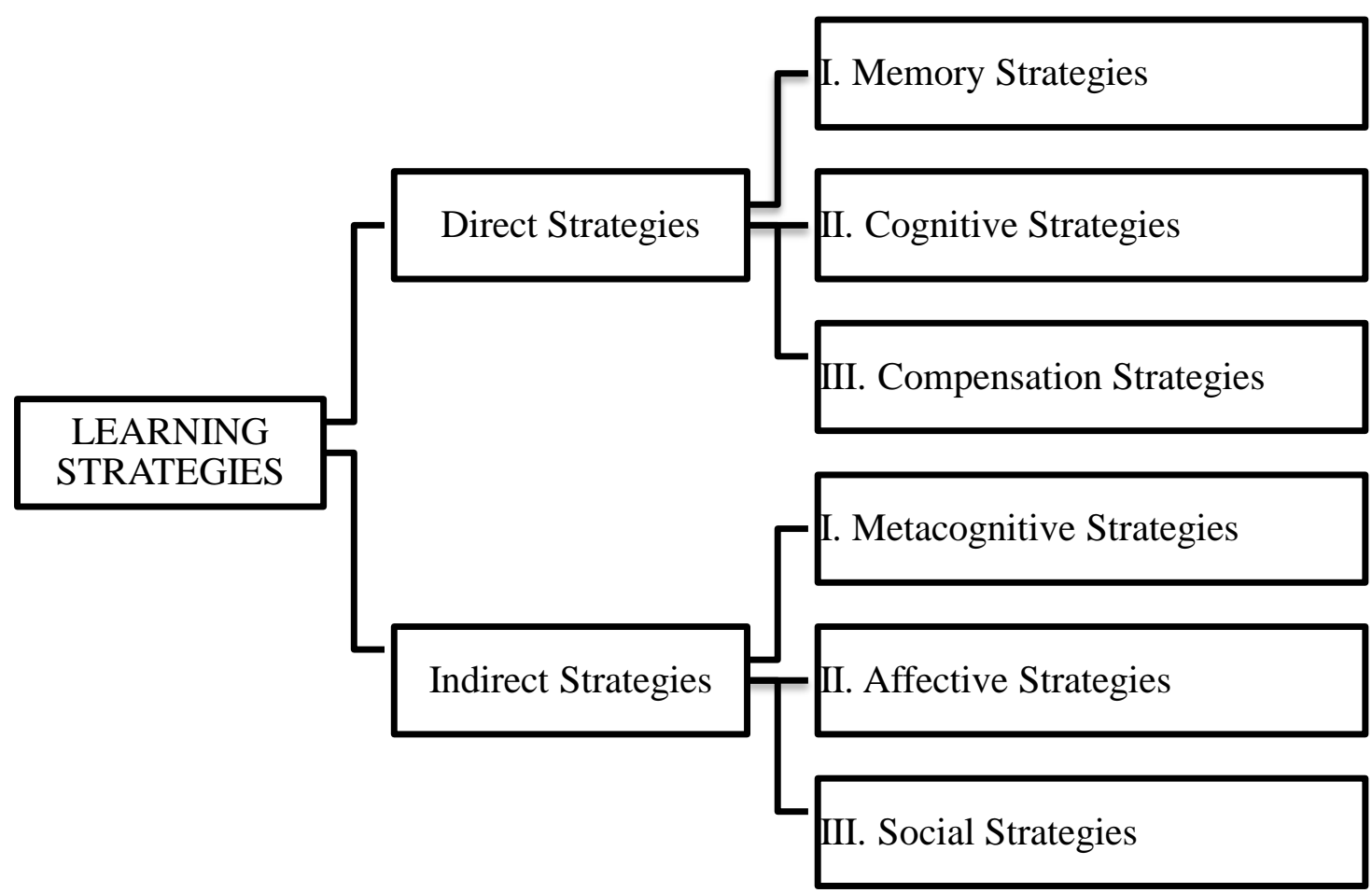

Diagram of Learning Strategies (Source: Oxford, 1990)

\section{a. Direct Strategies}

Oxford (1990, p.37) sees the direct strategies as a strategy which involved the target language directly. On direct strategies, language learning affected directly. Based on what the table explained, the direct strategies consist of memory strategies, cognitive strategies and compensation strategies.

\section{Memory Strategies}

Memory strategy helps the language learner receiving and saving the language into their brain. The focuses of this strategy are to make an individual connection of language items that help remember new language. This strategy is best used for remembering new 
vocabulary. Oxford (1990) stated that memory strategy is best used in memorizing new word and structures of the language, but the language learners need to use other strategies to mastering the language. It means that memory strategy will run maximally when the language learner used other strategies to support it. According to Oxford (1990), four contents existed inside this strategy, as follows;

\section{Creating mental linkages}

Language learner remember the vocabulary by making a mental picture of situan where the new word might be used. In other way, learner connect one word to other which have experienced by the language learner. A new word also can placing into context to expand their ability. The other term of mental linkages is grouping the words such as; smart, brilliant, awesome, great, beautiful, handsome, amazing, shy, messy, short, frightening, scary, etc.

\section{Applying images and sounds}

This strategies help language learner connect the sound and picture of a new vocabulary in order to help them remembering an exprssion and a new word. Language learner can use imagery, keywords, semantic mapping or representing sounds in memory for applying image and sound. Nowadays, many textbooks designed for children are full of pictures and colours. Imagery helps language learners convert an abstract word into more real (concrete) one. Then, representing sounds helps the language learner remember the new word according to the sound.

\section{Reviewing well}

In order to make the new information stable in the language learner memories, the learner needs to repeating the new information. The process of repeating the new information called structured reviewing. Putting the new information into storage is 
not enough. So that, there must be retrieval. Language learner may claim themselves as the reviewer well after they do on what information they have.

\section{Employing Actions}

The using of sensation and physical response present the way of employing kinestetic element. It contribute to remember new information. They are physically will open the learners' comprehension on remembering new information widely.

\section{Cognitive Strategies}

Cognitive strategy refers to cognition. These strategies enable learners to produce and understand language through different means. The function of cognitive strategy is transformation and manipulation of the target language by the language learner. The forms of cognitive language divided into four categories, that is called 'PRAC'. It is the acronym of Practicing, Receiving and Sending Messages, Analyzing and Creating Structure for Input and Output.

\section{Practising}

This strategies required the learner to do a lot of practice to achieve goals. It can be done by (1) repeating by saying over and over by listening the target language in several times, imitating the native speaker, (2) practicing the target language with sounds and writing system, (3) recognizing and using patterns or formula, (4) recombining; it can be attaching one phrase to other phrase to form a sentence, (5) practicing the target language such as; doing conversation, singing, watching film, doing strory telling, reading book, doing debate and other way of practicing.

2. Receiving and sending messages 
Getting the idea quickly such as skimming and scanning technique will help learner to get the main idea and the key point of the reading material. Then, sending messages to native speaker or produce outgoing messages in target languge can help the language learners in learning process.

\section{Analyzing and Reasoning}

This stratey divided into five strategies which are resoning deductively, analyzing expressions, analyzing contrastively, translating and transferring. Reasoning deductively used general rules and applying the rules to the target language. While analyzing expressions by determining the meaning of new expression and breaking it down into many parts, such as 'unconnected' is divided into 'un' and 'connected' meaning not connected. Next is analyzing contrastively. This strategy comparing the leaners' own language to target language from the vocabulary, sounds and grammar to find the difference and similarities such as 'pensil' (Bahasa Indonesia) and 'pencil' (English). Next is translating. It done by converting the expression of target language into native language. The last strategy is transferring by applying the new words or concepts from one language to other directly.

4. Creating structure for input and output

This strategy done by three ways which are taking notes, summarizing and highliting the important information. Language learners usually used this strategy in a classroom courses. The language learners can also summarizing in order to find important information of any media such as; megazine, article, websites and so on. Next strategy is highliting strategy. It done by underlying what is emphasized inside the reading material in order to focus on important information inside it. 


\section{Compensation Strategies}

Compensation strategies help language learners to fill the gap which missing in their learning problems. Language learners faced many problems while doing conversation or speech. This strategy enables language learners to make up for their restricted knowledge, especially in vocabulary. When they come across an unknown word, they can use a dictionary to look up the unknown word. Oxford (1990) categorized the compensation strategies into two forms which are guessing intelligently in listening and reading and overcoming limitations in speaking and writing.

\section{Guessing intelligently in listening and reading}

This strategy will be usefull when the language learners are supposed to read or listen particular information. It can be done by using linguistic clues and using other clues. The purpose of using linguistic clues is to guess the meaning of something read or heard in target language. For example, languge learner identified the word 'pra-sejarah' related to 'pre-history'. While using other clues means the language learner already familiar with the word. Then they tried to guess the meaning of the word. For example, the language learners doesn't know the meaning of 'bargain', then they guess related to selling and buying items because the word is often used in market.

\section{Overcoming limitations in speaking and writing}

Overcoming limitations in speaking and writing strategy is used while language learners don't know how to speak or express a word into target language. Then the language learners used mime, gesturing and moving in order to express the word. 


\section{b. Indirect Strategies}

Indirect strategies are those strategies which play a supportive role without being directly related to the interaction of the language itself. Strategies categorized within this group include metacognitive, affective, and social. Indirect strategies (that help the learning process internally, support and manage language learning without directly involving the target language), there are the metacognitive strategies which allow learners to control their cognition. Affective strategies which help to regulated emotions, motivations and, attitudes. Also, Social strategies help students learn through interaction with others (Oxford 1990, p. $135)$.

\section{Metacognitive Strategies}

To coordinate the learning process, these strategies allow learners to manage their cognition. These strategies grant language learners to create a plan while learning the target language. The language learning process will be more effective while the learners make a plan to guide them. There are three types of metacognitive strategies which are centring your learning, arranging and planning your learning, and evaluating your learning.

\section{Centring your learning}

Centering your learning help learners focussed on a certain language task such as listening. Centering your learning can be done by three actions which are overviewing and linking with already known material, paying attention and delaying speech to focus on listening. Overviewing and linking with already known material means that learners need to overviewing exhaustively the key concepts of a material and associating it with their knowledge. Paying attention means that learners should concentrate or pay attention to specific and important aspecs of the target language. They should ignore the distracters in language learning process. The last is delaying 
speech to focus on listening. It means that language learners keep focus on listening the target language first than speech the language.

\section{Arranging and planning your learning}

This strategy help the language learner to organize and plan in order to get the most out of language learning. Arranging and planning your learning divided into six strategies which are (1) finding out about language learning by reading a book, talking with native, improving the skill, (2) organizing by using and understanding a situation related to optional learning of target language; orginizing a schedule and another, (3) setting goal or short-term objective, (4) identifying the purpose of a language task by determining the aim of a certain language task involving reading, writing, listening and speaking, (5) planning for a language task, (6)seeking practices opportunities by creating and seeking out to practice the target language.

\section{Evaluating learning}

Evaluating learning help learner checking their performance in learning. Language learner could make a self monitoring. Then, they could analyze the source of an error and learn from it. This strategy is important in order to know the progress is made.

\section{Affective Strategies}

According to Oxford (1990, p.140), an effective strategy is one of the three indirect strategies which refers to attitudes, values, emotions and motivation. Affective strategies have a significant effect on language learning success or failure. Positive attitudes or emotion can affect the learning process become more effective, while negative emotion and attitude can 
hamper the language learning process. These strategies have three forms which are lowering your anxiety, encouraging yourself, and taking your emotional temperature.

1. Lowering your anxiety

Encouraging yourself can be done by three ways. The first is making positive statements by writing or saying a positive statement in order to feel more confident in learning process. Next is taking risk wisely and the last is rewarding yourself by giving reward for a good performance.

\section{Encouraging yourself}

Encouraging yourself can be done by three ways. The first is making positive statements by writing or saying a positive statement in order to feel more confident in learning process. Next is taking risk wisely and the last is rewarding yourself by giving reward for a good performance.

\section{Taking your emotional temperature}

This strategy deals with feelings and emotions related in learning the target language. This strategy can be done by listening to your body, writing a language learning diary such as sharing their feeling related to their learning process and share their writing to their teacher and discussing your feelling to others.

\section{Social Strategies}

This strategy also called a communication strategy. Social strategy deals with social interaction. Oxford divided these strategies into three subcategories which are asking the question, cooperating with others, and the last is empathizing with others.

\section{Asking questions}

This strategy is needed when the learners do not understand about certain topic and want to know more information about the topic. Asking questions helps 
the learner aids their understanding. This strategy can be done by (1) asking for verification or clarification related to the language skills such as listening, reading and asking for correction, (2) Asking for correction helps learner to know the correct information about the certain topic, (3) Take the mistake as the example and do not repeat it again.

\section{Cooperating with others}

Learners need to get feedback or enlightenment to help them growing up in their learning process. Cooperating with the master of the language helping learners to get additional and precious information and experience as well.

3. Emphasizing with others

Emphaty is important in supporting learners' skill. Another name of this strategy is developing cultural understanding. Giving emphaty to the culture of the language target is essential helping learners' awareness in their learning process.

\section{B. Self- Regulated Learning}

Self-regulated learning refers to our ability to understand and control our learning environments. To do so, we must set goals, select strategies that help us achieve those goals, implement those strategies, and monitor our progress towards our goals (Schunk, 1996). Few students are entirely self-regulated; however, those with better self-regulatory skills typically learn more with less effort and report higher levels of academic satisfaction (Pintrich, 2000; Zimmerman, 2000). Self-regulated learning theory is a relatively recent development in cognitive psychology, with its origins dating back to the social-cognitive learning theory of Albert Bandura (1997). 
Self-regulated learning, therefore, emphasizes the argentic and moldable role of learners in defining objectives and strategies, dynamically addressing the ongoing planning and undertaking of tasks, and recognizing and reflecting on one's perceptions and its influences alongside the learning task. As noted by Zimmerman (2002) SRL, therefore, goes beyond relying on skill-specific in-depth knowledge, but demands self-motivation, selfawareness, and behavior skills to effectively leverage that knowledge. This learner, centred adaptive ability to respond to different educational needs highlights the value of improved SRL abilities in supporting and sustaining lifelong learning and knowledge economy need of learners (Zimmerman, 20002; Littlejohn, Allison, Milligan \& Colin, 2015; Fontana, Milligan, Littlejohn \& Margaryan, 2015).

Experts agree that self-regulated learning includes three main components, including cognition, metacognition and motivation. Cognition includes skills necessary to encode, memorize, and recall information. Meta-cognition includes skills that enable learners to understand and monitor cognitive processes. Motivation includes beliefs and attitudes that affect the use and development of cognitive and metacognitive skills.

\section{Achievement}

Achievement is viewed basically as the competence a person has in an area of content. This competence is the result of many intellectual and nonintellectual variables, although in this study concentrate exclusively on the former. Another expert said that achievement is defined as measurable behavior in a standardized series of tests (Simpson \& Weiner, 1989).

Achievement is usually constructed and standardized to measure proficiency in school subjects. According to Bruce and Neville (1979), educational achievement as measured by standardized achievement test developed for school subjects. Achievement is regarded as action of completing or attaining by exertion. It subsumes anything won by exertion, a feat, a 
distinguished and successful action. Several subjects may be combined into an achievement battery for measuring general school proficiency either in point score or achievement age and perhaps achievement quotient.

\section{a. High Achievement}

The identifying characteristics of high potential include rapid learning, complex thinking, and creative problem solving (Coleman \& Cross, 2005) the student who has high achievement proper and planned reading habits than low achievers. They had a better home, health, social, emotional and school adjustment (Kapoor, 1987).

High achievement is defined as a level of performance that is higher than one would expect for students of the same age, grade, or experience. Specifically, proficiency is demonstrated by successfully mastering content (instructional) material beyond what is considered to be a grade-level curriculum, according to Kemendikbut, where in national standard KKM is expected to touch $75 / 100$ in every subject. The completeness criteria show the percentage of the level of competency attainment so that it is stated with a maximum number of 100 (one hundred). The maximum number of 100 is the ideal completeness criterion. The national completeness target is expected to reach a minimum of 75 . Academic units can start from the minimum completeness criteria below the national target and then increase it gradually. That means, the higher the score KKM of a subject and the higher the score of a student from the specified KKM will show the student's achievement.

\section{b. Low Achievement}

The students' low academic achievement on the exam can be defined as Low or weakness of the student's mark under the normal average in a study subject level as a result of a variety of reasons, including those related to the student himself, or those related to the 
family, social and academic environment (Al-Zoubi \& Younes, 2015). In line with the high achievement, if a student is not able to pass the specified KKM score, then the low achievement.

\section{RESEARCH METHODOLOGY}

Research design is the set of methods and procedures used in collecting and analysing measures of the variables specified in the research problem. The design of this study was survey research. The survey designed to know what is students' learning strategies of higher achievement in English among senior high school student. According to Fraenk el et al. (2012), survey research is to describe the characteristics of a group or population. The source of data in this research was the students of second-grade who have good records in academical score in English lesson. In obtaining the data, the researcher took three students who categorized as high achievers in their classes to be the participants of this research to know the students' learning strategies in the second-grader of SMA Dharma Pancasila Medan.

This study used questions interview as instrument. The questions is about learning strategies used by the students. The researcher adopt the Strategy Inventory for Language Learning (SILL) version 7.0 (ESL/EFL) by Oxford (1990). The questionnaire is translated into Bahasa Indonesia to avoid misinterpretation and misunderstanding by the students. This questionnaire is divided the language learning strategies into six types namely; memory strategies (6 items), cognitive strategies (7 items), compensation strategies (4 items), metacognitive strategies (5 items), affective strategies (4 items) and social strategies (5 items). 
After having the data of the interview, the researcher decided to use descriptive case study because it sets to describe the natural phenomena which stated in the research problem which has describing the language learning strategies used by the high achievers as the participants of this research.

\section{RESEARCH FINDINGS AND DISCUSSION}

Finding

The interviews' questions consist of six learning strategies which are Memory Strategies, Cognitive Strategies, Compensation Strategies, Metacognitive Strategies, Affective Strategies, and Social Strategies. In the transcription, student 1 refers to the first high achiever initials RW who has the highest score in the first grade. The student 2 refers to the second high achiever initials HK and the last is student 3 refers to third high achiever initials MRM.

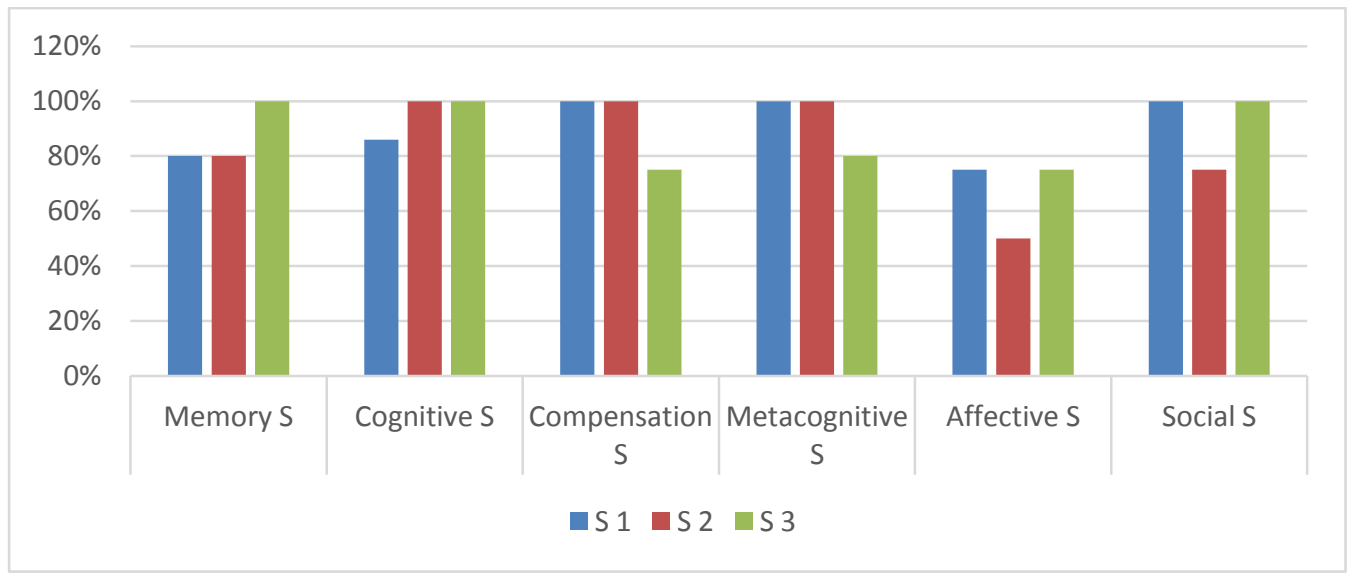

Discussion 
The purpose of answering this research question was to know the learning strategies used by the high achiever students of SMA Dharma Pancasila Medan. Based on the interview results, the first, the second, and third students tend used some of the strategies in their learning process. As has been said by Reiff (1992) students have individual characteristics related to their learning processes. The first students tend to use memory, metacognitive and compensation strategies as the main strategies. The second high achievers employed cognitive, metacognitive, and compensation strategies as the main strategies in learning English. Meanwhile, the third use memory, cognitive and social strategy as the main strategies.

Rubin (1975) mentioned a good language learner may have some special or use some mixed strategies. Therefore, choosing the best strategies is important when the learners learn about English. From the interview and the questionnaire session by the three high achiever students of SMA Dharma Pancasila Medan. The data showed the students combined all strategies in the learning process and used three strategies as the main strategy.

\section{CONCLUSIONS AND SUGGESTIONS}

\section{Conclusions}

This study aimed to know the strategies used by the highest achievers on the secondgrade of SMA Dharma Pancasila Medan. Based on the findings, the strategy that the high achiever's students of the second-grad of SMA Dharma Pancasila Medan, depending on the students themselves. The study's result was based on the answers using yes/no questions to determine whether students used direct or indirect strategies, from the interview session followed by the three high achiever students of SMA Dharma Pancasila Medan. The first students tend to used memory, metacognitive and compensation strategies as the main 
strategies. The second high achievers employed cognitive, metacognitive, and compensation strategies as the main strategies in learning English. Meanwhile, the third used memory, cognitive and social strategy as the main strategies. The data showed the high achiever's students in this school combined all strategies in the learning process and used three strategies randomly as the main strategy.

\section{Suggestion}

Based on the conclusion researcher decided to give some suggestions to the students, teacher, and the next researcher who want to conduct similar research.

For the students, learning strategies have highlighted the importance of strategy instruction, and it is the role of making learners more successful in their academic careers. Then the students should improve their learning strategies to get high achievement in English. It is also essential to find the appropriate strategies to facilitate the learning process. For the teacher, the research shown that every student has their own best learning strategies. It is suitable for the teacher to know the strategy that appropriates used by the students to get high achievement in English. For the next researcher who wants to conduct similar research, this study could be the introduction. The researcher then suggests the next researcher research the correlation between students' learning strategies and their achievement. 


\section{REFERENCES}

Aboe, R. M. (2019). Correlation Between Students Learning Styles and Their Learning Achievement. Journal of Teachers of English 5(1).

Afrizal, J. (2005). Language learning strategies of EFL University students at an Indonesian private university. Unpublished Master Thesis, Faculty of Education, University Kebangsaan Malaysia.

Algaber, S. \& Dasi, C. (2001). The Definition of Achievement and The Construction of Tests for Its Measurement. A Review of The Main Trends.

Chamot, A. U. \& El-Dinary (1999). Children's learning strategies in language immersion classrooms. The Modern Language Journal 83 (3).

Chilkiewicz, K. (2015). Direct Language Learning Strategies in the theory by Rebecca Oxford in English vocabulary acquisition at the age group of 11-12 year olds. World Scientific News.

Fernandes, L. (2014). Using English Literature For The Teaching Of English, International Journal of English Language and Literature Studies 3(2).

Lengkanawati, N.S. (1997). Contribution of Learning Strategies on Language Proficiency. Doctoral Dissertation, IKIP Bandung, Indonesia.

DOI: doi.org/10.24071/1lt.2018.Suppl2106 
Nurfaidah, (2016). Language Learning Strategies Among The High Achievers. Journal of Brawijaya University.

Oxford, Rebecca L. (1990). Language Learning Strategies-What Every Teachers Should Know. Massachusetts: Heinle \& Henle Publishers.

Phillips, V. J. (1991). A look at learner strategy use and language proficiency. CATESOL Journal. 4, 57-67.

Rüütmann, T., \& Kipper, H. (2011). Teaching Strategies for Direct and Indirect Instruction in Teaching Engineering, International Journal.

DOI: 10.1109/ICL.2011.6059556

Singh, K. (2011). Study of Achievement Motivation in Relation to Academic Achievement of Students. International Journal of Educational Planning \& Administration. 1(2) 161-171.

Xiangli Chang, Kang Xu, Yue Ma (2007) A Survey of Engineering Student's Use of English Language Learning Strategies. Journal of Asia TEFL 4 (2).

Yanfeng Hu, (2009). A Survey on the English Learning Strategy of the Rural High School Students and Urban High School Students, Journal of English Language and Literature Studies 2(3). 